\title{
Cryopreservation of orchid seeds through rapid and step
}

\section{freezing methods [version 1; peer review: 1 approved, 2}

\section{approved with reservations]}

\author{
Marco Cerna1, Paulina Valdivieso², Rino Cella³, Bence Mátyás(iD4, \\ Cristina Aucapiña ${ }^{1}$ \\ ${ }^{1}$ Carrera de Biotecnología de los Recursos Naturales, Universidad Politécnica Salesiana, Quito, Ecuador \\ 2Jardín Botanico "Orquídeas de Sarina", Quito, Ecuador \\ ${ }^{3}$ Laboratorio de biologia molecular vegetal, University of Pavia, Pavia, Italy \\ ${ }^{4}$ Grupo de Investigación Mentoria y Gestión del Cambio, Universidad Politécnica Salesiana, Cuenca, Ecuador
}

V1 First published: 20 Feb 2018, 7:209

https://doi.org/10.12688/f1000research.13622.1

Latest published: 20 Feb 2018, 7:209

https://doi.org/10.12688/f1000research.13622.1

\section{Abstract}

Ecuador has a great variety of climatic regions that potentiate biodiversity. The family Orchidaceae constitutes one of the most important of the country, having identified about 4032 species with a high degree of endemism, therefore the development and research of alternative methods of storage and conservation of species is a strategy of primary interest for researchers and for society in general. In cryopreservation, temperatures reach below $-190^{\circ} \mathrm{C}$ in order to paralyze the chemical reactions and keep the plant material viable for long periods. The present research focuses on the development of protocols for cryopreservation of seeds, aimed at the preservation of biodiversity, focusing on the family Orchidaceae, for the subsequent generation of a seed bank. The assays were performed on seeds of Epidendrum quitensium, Sobralia rosea, and Epidendrum anderssonii. Two freezing rates were tested: rapid freezing at $-196^{\circ} \mathrm{C}$; and step freezing at $-22^{\circ} \mathrm{C},-60^{\circ} \mathrm{C}$ to $196^{\circ} \mathrm{C}$, further analyzed four combinations from Dimethylsulfoxide DMSO, glycerol and sucrose (DMSO 1M; DMSO $1 \mathrm{M}+$ glycerol $1 \mathrm{M}$; DMSO $1 \mathrm{M}$ + sucrose $1 \mathrm{M}$; DMSO $1 \mathrm{M}+$ glycerol $0,5 \mathrm{M}+$ sucrose $0,5 \mathrm{M})$. The best results were obtained both in rapid and stepped freezing without the use of cryo-protective substances, by introducing the seeds directly into liquid nitrogen. Species of the genus Epidendrum presented a more efficient response in comparison to Sobralia. The viability of the seeds was evaluated by the tetrazolium test.

\section{Keywords}

Orchidaceae, Epidendrum, Sobralia, seeds, cryoconservation, liquid nitrogen, Tetrazolium.

\section{Open Peer Review}

\begin{tabular}{cccc} 
Approval Status & $? ?$ & \\
& 1 & 2 & 3 \\
\hline version 1 & $?$ & $?$ & \\
20 Feb 2018 & view & view & view \\
\hline
\end{tabular}

1. Alzbeta Novotna, University of Gdańsk, Gdańsk, Poland

2. Song-Jun Zeng, Chinese Academy of Sciences, Guangzhou, China

3. Éva Borbélyné Hunyadi, Research Institute for Organic Agriculture (ÖMKi), Budapest, Hungary

Any reports and responses or comments on the article can be found at the end of the article. 
Corresponding author: Bence Mátyás (bmatyas@ups.edu.ec)

Author roles: Cerna M: Conceptualization, Investigation, Methodology, Writing - Original Draft Preparation; Valdivieso P: Investigation, Methodology; Cella R: Investigation, Methodology, Writing - Original Draft Preparation; Mátyás B: Project Administration, Writing Original Draft Preparation, Writing - Review \& Editing; Aucapiña C: Investigation, Methodology, Writing - Original Draft Preparation

Competing interests: No competing interests were disclosed.

Grant information: The author(s) declared that no grants were involved in supporting this work.

Copyright: ( 2018 Cerna M et al. This is an open access article distributed under the terms of the Creative Commons Attribution License, which permits unrestricted use, distribution, and reproduction in any medium, provided the original work is properly cited. Data associated with the article are available under the terms of the Creative Commons Zero "No rights reserved" data waiver (CC0 1.0 Public domain dedication).

How to cite this article: Cerna M, Valdivieso $P$, Cella R et al. Cryopreservation of orchid seeds through rapid and step freezing methods [version 1; peer review: 1 approved, 2 approved with reservations] F1000Research 2018, 7:209

https://doi.org/10.12688/f1000research.13622.1

First published: 20 Feb 2018, 7:209 https://doi.org/10.12688/f1000research.13622.1 


\section{Introduction}

The Republic of Ecuador is located on the South American continent. From north to south the country is crossed by the Andes mountain range and has four climatic regions: Coast, Andes, Amazon and the Insular region ${ }^{1}$. Its position in the middle of the world, the luminous intensity, the ocean currents and the different altitudes produce 82 types of ecosystems (see Ministry of Environment document on ecosystems in Ecuador) There is a great variety of climatic regions that have an important effect in the diversification of plant formations ${ }^{2}$. Concerning the Orchidaceae family, in Ecuador as of 2010, 4032 species of orchids have been identified, of which $1714(42.5 \%)$ are endemic ${ }^{3} ; 4.5 \%$ of the orchids of the planet are found in Ecuador. Seed banks allow the conservation of the biodiversity ex situ and prioritize species used for food, medicine and those in danger of extinction. Orchidaceae is a large family with many endangered species and all of them are included in the Convention on International Trade in Endangered Species of Wild Fauna and Flora (CITES) I and $\mathrm{II}^{4}$. Cryopreservation is an efficient strategy to safeguard these species, but unfortunately, orchid seeds have short lifetimes; ${ }^{5}$ the longevity depends on the moisture content and storage temperature, so it is necessary to experiment with efficient storage systems for each species ${ }^{5}$. The advantages of cryopreservation are: storage for an indefinite period, genetic stability of the individuals, reduced infrastructure, can have independent energy and the stored genetic material does not require manipulation ${ }^{6}$.

Therefore, the objective of this research was to define protocols for cryopreservation of orchid seeds, in order to install a seed bank that promotes the conservation of vulnerable species.

\section{Methods}

\section{Collection of biological material}

The collection of plant material was made through the authorization of the Ministry of Environment of Ecuador No. 17-2011Investigación-B- DPMS/MAE,FloraX， N0. 08-2013-0869-I $C_{F} A U-F$ LO-DAPI $-U N O-M A E$ and the Botanical Garden "Orquídeas de Sarina" patent No. 006-2015- FLO-DPAP- MA.

The cryopreservation tests were developed with the seeds of 3 species: Epidendrum quitensium Rchb.f., Sobralia rosea Poepp. \& Endl. and Epidendrum anderssonii Hágsater \& Dodson (Figure 1). The cryopreservation tests were developed with 3 species:

- 2392 Epidendrum quitensium Rchb.f., (0 $17^{\prime} 52.1$ ' $\mathrm{N} 78^{\circ}$ 22'33.3”W 3200 msnm)

- 2420 Sobralia rosea Poepp.\& Endl. $\left(0^{\circ} 52^{\prime} 11.8^{\prime} \mathrm{N} 78^{\circ}\right.$ 26'53.8'W 600 msnm)

- 2706 Epidendrum anderssonii Hágsater\&Dodson $\left(0^{\circ}\right.$ 50 '36.2”N $78^{\circ} 25^{\prime} 01.5$ ”'W $1200 \mathrm{msnm}$ )

The species pertain to three different altitudes and were selected from many sources and have capsules with viable seeds. The seeds collected from the forest were stored in an absorbant paper bag with respective codes for the plant, after they were stored in a Ziplock bag with rice of $12 \%$ humidity.

\section{Freezing speed}

Two types of freezing were tested, suggested according to Mroginski et $a l^{7}$. The sample units had $0.2 \mathrm{~g}$ of seeds stored in cryo tubes (091.11.102, ISOLAB, Wertheim, Germany) of $2 \mathrm{ml}$. Steps of freezing: freezing was carried out in the following sequence, $0^{\circ} \mathrm{C}$ for 1 hour by placing the samples in an refrigerator (Electrolux, Stockholm, Sweden), $-22^{\circ} \mathrm{C}$ for 1 hour placing the seeds in a freezer (Selecta Templow, Barcelona, Spain), $-60^{\circ} \mathrm{C}$ for 1 hour inserting the seeds in an ultra low temperature freezer (New Brunswick Scientific, Edision, NJ, USA), then the seeds were held at $196^{\circ} \mathrm{C}$ by submerging the samples in liquid nitrogen contained in a thermal container. Finally the samples were placed in racks and stored in a thermal tank (STATEBOURNE biorack 5400, Washington, UK). Rapid freezing: the samples were placed directly in liquid nitrogen at $196^{\circ} \mathrm{C}$ by immersion using a procedure similar to that used in steps of freezing. In addition, four combinations of cryo preservatives were analyzed: 1- DMSO 1M (Fisher Scientific, Hampton, NH, USA); 2-DMSO 1M (Fisher) - glycerol 1M; 3- DMSO 1M (Fisher) sucrose $1 \mathrm{M}$; 4- DMSO $1 \mathrm{M}$ (Fisher) - glycerol $0.5 \mathrm{M}$ - sucrose $0.5 \mathrm{M}$ (Fisher) (Table 1).
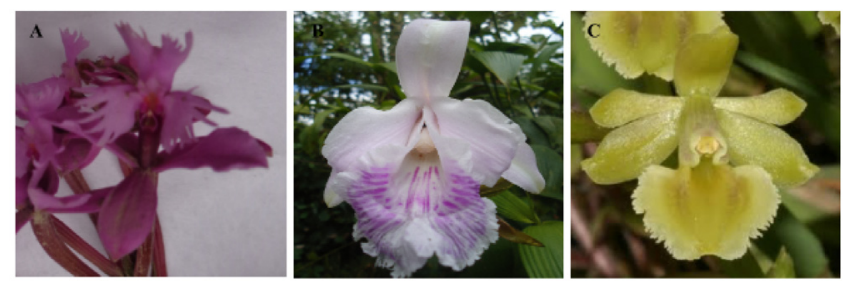

Figure 1. Orchids used for cryopreservation tests. A) Epidendrum quitensium, B) Sobralia rosea, C) Epidendrum anderssonii.

Table 1. System design and freezing seed symbology used for cryoprotective substances and their concentrations. M: molar.

\begin{tabular}{|c|c|c|c|}
\hline \multicolumn{4}{|c|}{ TYPE OF FREEZING } \\
\hline \multicolumn{2}{|l|}{ GRADUAL (P) } & \multicolumn{2}{|l|}{ Rapid (F) } \\
\hline \multicolumn{2}{|c|}{$0^{\circ} \_-22^{\circ} \_-60^{\circ} \_-196$} & \multicolumn{2}{|l|}{$-196^{\circ}$} \\
\hline CRYOPRESERVANTES & SYMBOL & CONCENTRATION & \\
\hline NONE & $\mathrm{N}$ & & \\
\hline DMSO & $\mathrm{D}$ & $1 \mathrm{M}$ & \\
\hline GLYCEROL & G & $1 \mathrm{M}$ & $0,5 \mathrm{M}$ \\
\hline SUCROSE & S & $1 \mathrm{M}$ & $0,5 \mathrm{M}$ \\
\hline \multicolumn{4}{|c|}{ COMBINATION OF CRYOPRESERVANTES } \\
\hline NONE & & & $\mathrm{N}$ \\
\hline $\begin{array}{l}\text { DMSO } \\
1 \mathrm{M}\end{array}$ & & & $\mathrm{D}$ \\
\hline $\begin{array}{l}\text { DMSO } \\
1 \mathrm{M}\end{array}$ & $\begin{array}{l}\text { GLYCEROL } \\
1 \mathrm{M}\end{array}$ & & DG \\
\hline $\begin{array}{l}\text { DMSO } \\
1 \mathrm{M}\end{array}$ & $\begin{array}{l}\text { SUCROSE } \\
1 \mathrm{M}\end{array}$ & & DS \\
\hline $\begin{array}{l}\text { DMSO } \\
1 \mathrm{M}\end{array}$ & $\begin{array}{l}\text { GLYCEROL } \\
0,5 \mathrm{M}\end{array}$ & $\begin{array}{l}\text { SUCROSE } \\
0,5 \mathrm{M}\end{array}$ & DGS \\
\hline
\end{tabular}


Seed viability

Seed viability was tested after freezing. Briefly, $5 \mathrm{mg}$ of seeds was added to $1.5 \mathrm{ml}$ of $10 \%$ sucrose solution and left at $25^{\circ} \mathrm{C}$ for 24 hours, the seeds were washed with water and $1 \mathrm{ml}$ of triphenyl tetrazolium chloride solution (TTC, 1\%) (SigmaAldrich, St Louis, MI, USA) was added, and then incubated at $40^{\circ} \mathrm{C}$ for 24 hours. Finally, the seeds were washed with sterilised water and observed under the microscope with a $4 \mathrm{x}$ lens (MC100Led, MI-CROS, St. Veit/Glan, Austria). The process for calculating the TTC method was carried out as follows: -Observe the seeds in microscope using lense $4 \mathrm{X}$. -Identify viable seeds and non viable seeds. -Use cross multiplication to determine the average of viability of all seeds.

\section{Statistical analysis}

The experimental design $2 \times 5$ with three repetitions was applied to analyse the freezing methods (Table 2). The results were analyzed by unidirectional ANOVA with $95 \%$ confidence. To determine the best treatments the Duncan test was used. This analysis was carried out with RStudio 3.1 (package: Agricolae).

\section{Results}

The seeds were considered viable when red coloration of the embryo was observed ${ }^{8}$ (Figure 2).

According to the data obtained (Table 3, Figure 3), there is a significant difference in the results when comparing the data between the species and between the treatments. According to

Table 2. Experimental design, testing orchid seeds cryopreservation - design $2 \times 5$ with three repetitions, Symbols (N: none, D: DMSO, G: glycerol, S: sucrose, P: Freeze steps, R: Rapid).

\begin{tabular}{|c|c|c|c|c|c|c|}
\hline & \multicolumn{3}{|c|}{ STEP (P) } & \multicolumn{3}{c|}{ FAST (R) } \\
\hline & P1 & P2 & P3 & R1 & R2 & R3 \\
\hline N & PN1 & PN2 & PN3 & RN1 & RN2 & RN3 \\
\hline D & PD1 & PD2 & PD3 & RD1 & RD2 & RD3 \\
\hline DG & PDG1 & PDG2 & PDG3 & RDG1 & RDG2 & RDG3 \\
\hline DS & PDS1 & PDS2 & PDS3 & RDS1 & RDS2 & RDS3 \\
\hline DGS & PDGS1 & PDGS2 & PDGS3 & RDGS1 & RDGS2 & RDGS3 \\
\hline
\end{tabular}
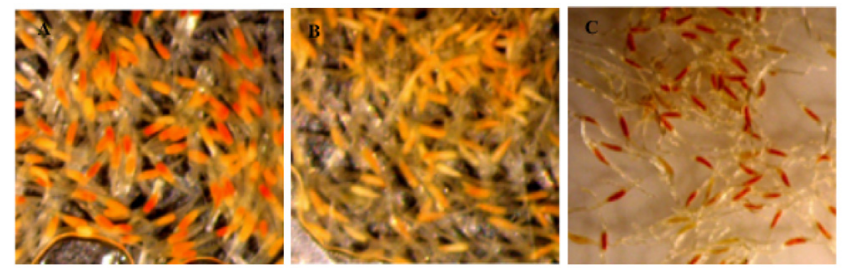

Figure 2. TTC-stained seeds subjected to the "stepped" cryopreservation process without any cryopreservation substances. Viable seeds (dark red embryos) and non-viable (pale embryos). A) Epidendrum quitensium, B) Sobralia rosea, C) Epidendrum anderssonii. the Duncan test, the best treatments were rapid freezing and step freezing without the use of cryopreservatives. The least efficient treatment was step freezing with the use of DMSO as a cryopreservant (Table 4). The species Epidendrum quitensium and Epidendrum anderssonii showed better results (Figure 4).

Dataset 1.TTC-stained seeds subjected to the "Rapid" cryopreservation process: Epidendrum quitensium

http://dx.doi.org/10.5256/f1000research.13609.d194564

Dataset 2. TTC-stained seeds subjected to the "Rapid" cryopreservation process: Sobralia rosea

http://dx.doi.org/10.5256/f1000research.13622.d194234

Dataset 3. TTC-stained seeds subjected to the "Rapid" cryopreservation process: Epidendrum anderssonii

http://dx.doi.org/10.5256/f1000research.13622.d194235

Dataset 4. Percentage for seed viability calculations

http://dx.doi.org/10.5256/f1000research.13622.d194236

Table 3. Cryopreservation of orchid seeds. Values represent percentage of viability assessed by the TTC method, N: cryo preservative; D: DMSO; S: sucrose; G: glycerol.

\begin{tabular}{|l|l|l|l|l|l|l|}
\hline CI & Species & N & D & DG & DS & DGS \\
\hline 2392 & $\begin{array}{l}\text { Epidendrum } \\
\text { quitensium }\end{array}$ & 83.20 & 54.87 & 83.20 & 46.36 & 47.01 \\
\hline 2420 & Sobralia rosea & 55.93 & 12.29 & 10.72 & 19.34 & 18.88 \\
\hline 2706 & $\begin{array}{l}\text { Epidendrum } \\
\text { anderssonii }\end{array}$ & 93.50 & 40.88 & 51.81 & 62.84 & 55.94 \\
\hline 2392 & $\begin{array}{l}\text { Epidendrum } \\
\text { quitensium }\end{array}$ & 74.79 & 48.29 & 62.87 & 52.79 & 51.73 \\
\hline 2420 & Sobralia rosea & 65.60 & 50.15 & 55.04 & 52.72 & 52.52 \\
\hline 2706 & $\begin{array}{l}\text { Epidendrum } \\
\text { anderssonii }\end{array}$ & 84.49 & 18.57 & 41.07 & 63.08 & 60.10 \\
\hline
\end{tabular}

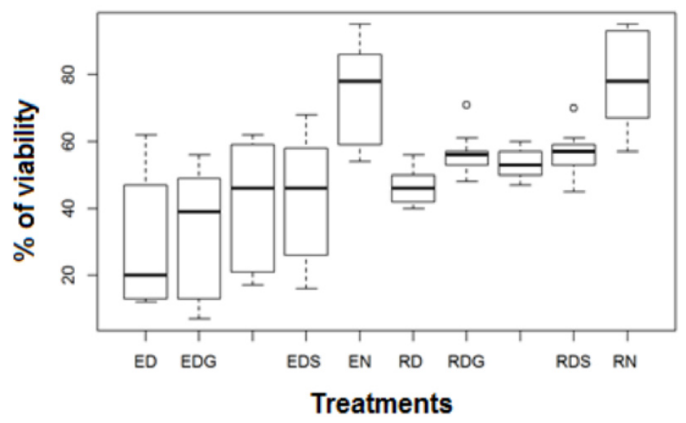

Figure 3. Seed cryopreservation: variability by treatment. Results obtained using the Tukey test. 
Table 4. Duncan test groups obtained after cryopreservation test. Results are given as orchid seed viability percentage; $a, b, c$ and $\mathrm{d}$, indicate groups with statistical significance. Classification was made under an alpha of 0.01 , and 78 degrees of freedom for error. Symbols (treatment): N: none, D: DMSO, G: glycerol, S: sucrose. Symbols (types of freezing)

P: Freeze steps, R: Rapid.

\begin{tabular}{|l|l|l|l|l|l|l|l|}
\hline$\#$ & Treatment & Mean & & & & & \\
\hline 1 & RN & 78.00 & a & & & & \\
\hline 2 & PN & 74.66 & a & & & & \\
\hline 3 & RDG & 56.66 & & b & & & \\
\hline 4 & RDS & 56.00 & b & & & \\
\hline 5 & RDGS & 53.33 & b & c & & \\
\hline 6 & RD & 46.55 & b & c & & \\
\hline 7 & PDS & 43.00 & & c & d & \\
\hline 8 & PDGS & 41.88 & & c & d & \\
\hline 9 & PDG & 33.33 & & & d & e \\
\hline 10 & PD & 28.55 & & & & e \\
\hline
\end{tabular}

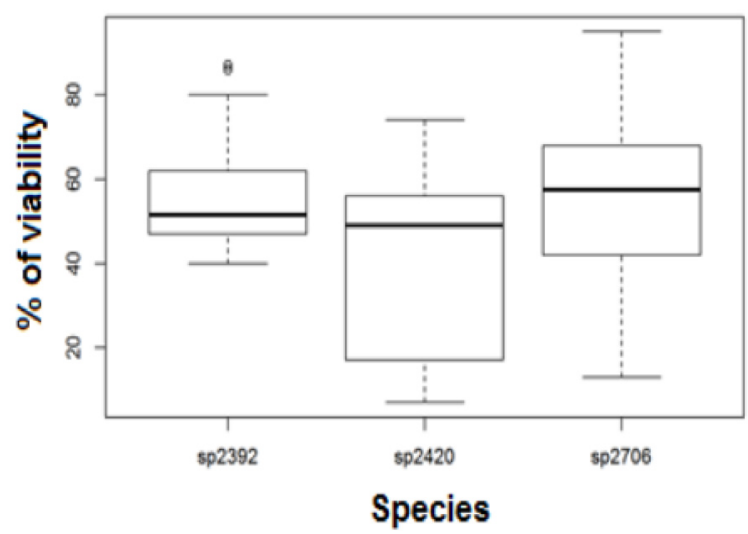

Figure 4. Cryopreservation of seeds: variability by species. Results obtained using the Duncan test, sp2706 (T57.2), sp2392 (T 57.03), sp2420(T39.37).

\section{Discussion}

Currently, cryopreservation is a safe and cost-effective option for the conservation of endangered species ${ }^{9}$. In the present investigation, a protocol was developed for cryopreservation of orchid seeds that provides a high percentage of viability, is easy to apply and economical. The seeds of orchids frozen at $-196^{\circ} \mathrm{C}$ can be kept alive with a moisture content of $12 \%$ and do not require cryo-protective substances, confirming what is described by Iriondo et al. and others ${ }^{10,11}$. The use of cryopreservatives is recommended for seeds with a high moisture content, as stated by Reed and others ${ }^{12-14}$. Furthermore, Harding ${ }^{15}$ states that it is necessary to demonstrate the genetic stability of plants regenerated from cryopreserved plant material to approve their release and reintroduction into the environment; but to date, there have been no reports showing changes at the phenotypic, biochemical, chromosomal or molecular levels attributed to storage systems by cryoconservation ${ }^{14}$. The cryoconservation method that gave the best results was the "Rapid" freezing without the addition of any cryopreservative substance.

\section{Data availability}

Dataset 1: TTC-stained seeds subjected to the "Rapid" cryopreservation process: Epidendrum quitensium 10.5256/f1000research. 13622.d194233 $3^{15}$

Dataset 2: TTC-stained seeds subjected to the "Rapid" cryopreservation process: Sobralia rosea 10.5256/f1000research.13622. d194234 ${ }^{16}$

Dataset 3: TTC-stained seeds subjected to the "Rapid" cryopreservation process: Epidendrum anderssonii. 10.5256/ f1000research.13622.d194235 ${ }^{17}$

Dataset 4: Percentage for seed viability calculations 10.5256/ f1000research.13622.d194236 ${ }^{18}$

\section{Competing interests}

No competing interests were disclosed.

\section{Grant information}

The author(s) declared that no grants were involved in supporting this work.
1. Neill D: Geografía. En Jørgensen P, \& P. \&. S.L.-Y. (Ed.), Catalogue of the vascular plants of Ecuador. Missouri Bot. Gard. 1999; 1181 Reference Source

2. Endara L, Jost L: Orchidaceae. En León-Yánez S, Valencia R, Pitman N Endara L, Ulloa C, Navarrete H, El libro rojo de las especies endémicas del Ecuador. (Segunda edición ed.). Quito, Ecuador: Herbario QCA, Pontificia Universidad Católica del Ecuador. 2010.

3. Cerna M, Aucapiña C, López, P: Definición de protocolos para el uso de fitohormonas en el crecimiento de orquídeas a nivel in vitro. (Olmedo GF, Ed.) ESPE: Revista Congreso de Ciencia y Tecnología, 2016; 11. : 12-19. Reference Source
4. Wolfgang S: Orchid seeds- Nature's tiny treasures. London: Kew Royal Botanical Garden. Recuperado el 12 de Enero de 2015, de, 2013. Reference Source

5. Hine A, Vargas $\mathrm{P}$, Abdelnour A: Crioconservación de semillas de teca (Tectona grandis L.f). Agronomía Costarricence. 2013; 37(1): 51-60. Reference Source

6. Mroginski L, Roca W, Kartha K: Crioconservación del germoplansma. En Roca W \& L M, Cultivos de tejidos en la agricultura: Fundamentos y aplicaciones. Cali, Colombia: CIAT. 1991: 715-730. Reference Source

7. Machado-Neto N, Custódio C, Hosomi S, et al:: Orchid seed Stores for 
Sustainable Use: Fast protocol for Tetrazolium test in orchid seeds. OSSSU. ORG. 2009

Reference Source

8. Gonzáles M, Engelmann F: Crioconservación de plantas en América Latina y e Caribe. San José, Costa Rica: IICA. 2013. Reference Source

9. Iriondo J, Pérez C, Pérez-García F: Effect of seed storage in liquid nitrogen on germination of several crop and wild species. Seed Sci Technol. 1992; 20 : 165-171.

Reference Source

10. Abdelnour A, Alvarado C: Crioconservación de semillas y protocormos de especies de la familia Orchidaceae en peligro de extinción. Costa Rica: Instituto Tecnológico de Costa Rica. 2013.

Reference Source

11. Reed BM: Implementing cryogenic storage of clonally propagated plants. Cryo Letters. 2001; 22(2): 97-104.

PubMed Abstract

12. Gonzales MT, Engelmann F: Cryopreservation of plant germplasm using the encapsulation-dehydration technique: review and case study on sugarcane.
Cryo Letters. 2006; 27(3): 155-168 PubMed Abstract

13. Engelmann F: Integration of cryopreservation in plant genetic resource conservation strategies in France. Cryo Letters. 2010; 31-82.

14. Harding K: Genetic integrity of cryopreserved plant cells: a review. Cryo Letters. 2004; 25(1): 3-22. PubMed Abstract

15. Cerna M, Valdiviezo P, Cella R, et al.: Dataset 1 in: Cryopreservation of orchid seeds through rapid and step freezing methods. F1000Research. 2018. Data Source

16. Cerna M, Valdiviezo P, Cella R, et al:: Dataset 2 in: Cryopreservation of orchid seeds through rapid and step freezing methods. F1000Research. 2018. Data Source

17. Cerna M, Valdiviezo P, Cella R, et al.: Dataset 3 in: Cryopreservation of orchid seeds through rapid and step freezing methods. F1000Research. 2018. Data Source

18. Cerna M, Valdiviezo P, Cella R, et al.: Dataset 4 in: Cryopreservation of orchid seeds through rapid and step freezing methods. F1000Research. 2018. Data Source 


\section{Open Peer Review}

\section{Current Peer Review Status:}

\section{Version 1}

Reviewer Report 11 July 2018

https://doi.org/10.5256/f1000research.14799.r33998

(c) 2018 Hunyadi É. This is an open access peer review report distributed under the terms of the Creative Commons Attribution License, which permits unrestricted use, distribution, and reproduction in any medium, provided the original work is properly cited.

\section{Éva Borbélyné Hunyadi}

Research Institute for Organic Agriculture (ÖMKi), Budapest, Hungary

In the paper entitled "Cryopreservation of orchid seeds through rapid and step freezing methods" written by Marco Cerna et al. two types of freezing technique were tested by the seeds of 3 species:

Epidendrum quitensium Rchb.f., Sobralia rosea Poepp. \& Endl. and Epidendrum anderssonii Hágsater \& Dodson.

The authors present step freezing and rapid freezing methods for cryopreservation purposes. There was a significant difference in the results between the species and between the treatments. The cryoconservation method that provided the best results was the "Rapid" freezing, without the addition of any substance.

The introduction is well structured, helping the readers to understand the issue the method tries to solve. Considering that it is a research note the methodology is very detailed.

Nevertheless, in my opinion it is important to highlight the viability of the developed method on a wider spectrum if possible. In the current form of the Discussion, only general statements can be found regarding the viability of the developed method.

A more concrete concluding sentence is missing that could answer the following question:

For what kind of other plants, could this method be useful?

If the developed method can be applied "only" for orchid seeds, a concluding sentence should be placed in the Discussion, stating the limiting factors (in terms of species) of the method. Although in this study only 3 species were examined, I believe that its important to inform the readers about the authors' recommendation regarding the potential usefulness in other species.

Competing Interests: No competing interests were disclosed. 


\section{I confirm that I have read this submission and believe that I have an appropriate level of expertise to confirm that it is of an acceptable scientific standard.}

Reviewer Report 09 April 2018

https://doi.org/10.5256/f1000research.14799.r32906

(C) 2018 Zeng S. This is an open access peer review report distributed under the terms of the Creative Commons Attribution License, which permits unrestricted use, distribution, and reproduction in any medium, provided the original work is properly cited.

\section{Song-Jun Zeng}

Key Laboratory of South China Agricultural Plant Molecular Analysis and Gene Improvement \& Guangdong Provincial Key Laboratory of Applied Botany, South China Botanical Garden, Chinese Academy of Sciences, Guangzhou, China

The authors described a protocol for cryopreservation of seeds of three tropical orchids in liquid nitrogen (LN). They tested rapid and progressive cooling with the controlled temperature at $0^{\circ} \mathrm{C}$, $22^{\circ} \mathrm{C},-60^{\circ} \mathrm{C}$ and $-196^{\circ} \mathrm{C}$. They also included the application of three different cryoprotectants such as DMSO, glycerol and sucrose. The viability of tested seeds was checked using tetrazolim test. The protocol might have potential for the cryopreservation of these orchids. However, the manuscript cannot be accepted to publish at present and need major revision for the following main reasons:.

1. Abstract: Authors could not bring the conclusion 'Species of the genus Epidendrum presented a more efficient response in comparison to Sobralia.', because only one species was be tested in the this manuscript.

2. Introduction: Orchidaceae is a large family with many endangered species and all of them are included in the Convention on International Trade in Endangered Species of Wild Fauna and Flora (CITES) I and II.

And should be revised as 'or'. Current research of orchid Cryopreservation should be introduced in the section.

3. Methods: DPMS/MAE,FloraX the behind of ",' should have a blank.

4. Epidendrum quitensium Rchb.f., Sobralia rosea Poepp. \& Endl. and Epidendrum anderssonii Hágsater \& Dodson Rchb.f., Poepp. \& Endl. and Hágsater \& Dodson should not be italic.

\section{2392 Epidendrum quitensium Rchb.f., 2420 Sobralia rosea Poepp.\& Endl., Epidendrum} anderssonii Hágsater \& Dodson

Epidendrum quitensium, Sobralia rosea, Epidendrum anderssonii should be italic.

6. Figure 1: Epidendrum quitensium, Sobralia rosea, Epidendrum anderssonii should be italic.

7. Figure 2: A) Epidendrum quitensium, B) Sobralia rosea, C) Epidendrum anderssonii

A, B, C should be labelled in Photos. 
8. Figure 3: What is ED, EDD.......what is the meaning of "E"?

9. sp2706 (T57.2), sp2392 (T 57.03), sp2420(T39.37), should be replaced by Latin name of orchids species.

10. Discussion: The discussion should be rewritten. There were few relevant literatures of orchid Cryopreservation were cited in this manuscript. There have lots of related literatures for orchid Cryopreservation at present, which should be discussed and what is the innovation of the manuscript?

11. All the source data should be executed by statistical analysis.

Competing Interests: No competing interests were disclosed.

I confirm that I have read this submission and believe that I have an appropriate level of expertise to confirm that it is of an acceptable scientific standard, however I have significant reservations, as outlined above.

Reviewer Report 28 March 2018

https://doi.org/10.5256/f1000research.14799.r31828

(C) 2018 Novotna A. This is an open access peer review report distributed under the terms of the Creative Commons Attribution License, which permits unrestricted use, distribution, and reproduction in any medium, provided the original work is properly cited.

\begin{abstract}
Alzbeta Novotna
Department of Plant Taxonomy and Nature Conservation, University of Gdańsk, Gdańsk, Poland

The authors describe in the presented manuscript titled "Cryopreservation of orchid seeds through rapid and step freezing methods" a new protocol for cryopreservation of seeds of three tropical orchids in liquid nitrogen (LN). They tested rapid and progressive cooling with the controlled temperature at $0^{\circ} \mathrm{C},-22^{\circ} \mathrm{C},-60^{\circ} \mathrm{C}$ and $-196^{\circ} \mathrm{C}$. They also included the application of three different cryoprotectants such as DMSO, glycerol and sucrose. The viability of tested seeds was checked using tetrazolim test. Red coloured embryos were considered as the main indicator of the preserved viability of the tested seeds. I suppose that this work brings a novelty to a cryoscience research, especially due to the geographical origin of the studied material. Neotropical Orchidaceae should be prioritized in various research studies for their ecological vulnerability and/or a shortage of knowledge. Especially, the research achievements from such country as Ecuador (the orchid biodiversity hotspot), are important for science. However, numerous modifications and a deep correction of the text should be accomplished.

1. English correction is strongly recommended throughout the whole text. There are many errors in English grammar in the current form of the manuscript, which cause huge difficulties in text reading.

2. Abstract: The authors should be focused on the topic of cryopreservation. The first two
\end{abstract}


sentences in the abstract are out of topic. Moreover, the number of the orchid species (provided number 4032) is not correct. The authors should consider to check the work of D. Neill published in 2015 (¿Cuantas especies nativas de plantas vasculares hay en Ecuador?; Revista Amazónica Ciencia y Tecnología) and Cataloque of the Vascular Plants of Ecuador available on www.tropicos.org, for example.

3. Abstract, sentence "In cryopreservation, temperatures reach below $-190^{\circ} \mathrm{C}$ " should be rephrased because the cryostorage is a long-lasting preserving of studied material at temperature of $-80^{\circ} \mathrm{C},-130^{\circ} \mathrm{C}$ upto $-196^{\circ} \mathrm{C}$, which is the temperature of the liquid nitrogen.

4. Abstract, the authors should rephrase the sentence "The present research focuses on......" because of repetition of the verb to focus. Instead of "...for a subsequent generation of a seed bank" to use "for future seed collection" for example.

5. Abstract, "the use of cryo-protective substances", better to use the term "cryoprotectants".

6. Introduction; The first half of the abstract is out of the topic of cryopreservation. The authors should be focused on this topic. Moreover, the authors should provide much more citations regarding this topic and discuss shortly the history of cryopreservation of seeds with more interest in orchid seeds. There are many available papers regarding this topic.

7. Methods; The first paragraph should be included in "Acknowledgement" at the end of the paper, not in methods. However, each part of the Methods should be provided with a number, e.g. 1. 1 Collection of the seed material. The sentence "The cryopreservation test were developed with 3 species" is repetition of the first sentence of this paragraph.

8. The authors should use "a.s.l."as the abbreviation for above sea level; the provided abbreviation "msnm" is not understandable. The part of the sentence" The species pertain to three different altitudes..... " is a repetition of the information written before. Authors write "......were selected from many sources", what does it mean? The authors should provide more detailed information about the sources. Then, the part of the sentence ..."and have capsules with viable seeds" does not bring the clear information. Were the capsules opened during collection or not? When did the authors collect the seeds (the date)?

9. Methods; Freezing speed. Better to rewrite the title, e.g. Cryopreservation of the seeds

10. This part should be shorten. Besides, the citation of the first sentence Mroginski et al. does not correspond with the number 7 . Totally different citation is written under this number. The authors should check the citations of provided literature in the text. Moreover, the authors should provide the information about duration of cryostorage. This very important information is missing.

11. In the paragraph "Freezing speed" the authors provide information about placing the tested orchid seeds under the temperature $0^{\circ} \mathrm{C}$ in a refrigerator. However, this fact is not written in the abstract.

12. The authors should eliminate "...., contained in a thermal container".

13. The sentence "Finally the samples were places in racks and store in thermal tansk......" should be eliminated, because it is not understandable.

14. Freezing speed; In addition,.... should be eliminated because the application of cryoprotectants is one of the main objectives of this research paper. It is not something additional.

15. Why did the authors not test application of sucrose and glycerol individually?

16. The authors should clearly demonstrate, which treatment is considered as a control.

17. Table 1 should be deleted, because all the information given in this table is written in the text.

18. Figure 1; Title should be improved, e.g. "Orchid species used in this study". 
19. The paragraph of "Seed viability" should be eliminated. Instead just one sentence with a citation of the work, where this method was used as first, should be placed at the end of the previous paragraph.

20. Statistical analysis; The authors should explain better of the meaning "The experimental design $2 \times 5^{\prime \prime}$. It is not clear from the written text.

21. Results; The sentence "The seeds were considered viable when red....." is actually the part of Material and methods.

22. Results; this part should be re-written. The information should be provided more clearly.

23. Table 3; What is CI? Better to use term "Gradual" instead of "step". The abbreviations of each treatment are already provided in Material and Methods.

24. Figure 3; Authors should provide information about the meaning of " $E$ " (in e.g. ED, EDG) and "R" (in e.g. RD, RDG).

25. Figure 4; Authors should provide information about the meaning of sp2392, sp2420 and sp2706. It is not clear.

26. Discussion; First, the obtained main result should be provided and discussed with much more available literature. Especially, the authors should compare their findings with achievements in other studies. The provided references are very limited. The works dealing with cryostorage of seeds of other plant families should be included. The given number of cited paper in discussion does not correspond to the number provided in the References.

Competing Interests: No competing interests were disclosed.

Reviewer Expertise: Isolation, molecular determination and cryopreservation of orchid mycorrhiza fungi and associated bacteria. Experienced with orchid seed banking techniques.

\section{I confirm that I have read this submission and believe that I have an appropriate level of expertise to confirm that it is of an acceptable scientific standard, however I have significant reservations, as outlined above.}

The benefits of publishing with F1000Research:

- Your article is published within days, with no editorial bias

- You can publish traditional articles, null/negative results, case reports, data notes and more

- The peer review process is transparent and collaborative

- Your article is indexed in PubMed after passing peer review

- Dedicated customer support at every stage

For pre-submission enquiries, contact research@f1000.com

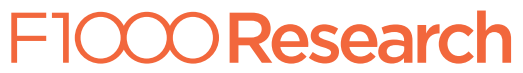

